(RESEARCH ARTICLE)

\title{
Antidiabetic and anti-inflammatory effects of two Fabaceae extracts against streptozotocin induced diabetic impairment in male rats
}

\author{
Abdou Heba Mohamed 1, ${ }^{*}$, Mohammed Nema Abd El-Hameed 1, Hussein Hussein Khamis ${ }^{1}$, Ghazaly Kamal \\ Sharkawy ${ }^{2}$ and Abd El-latif Heba Samir ${ }^{2}$ \\ ${ }^{1}$ Zoology Department, Faculty of Science, Alexandria University, Egypt. \\ ${ }^{2}$ Zoology, Biological and Geological Sciences Department, Faculty of Education, Alexandria University, Egypt.
}

Publication history: Received on 20 May 2020; revised on 02 June 2020; accepted on 08 June 2020

Article DOI: https://doi.org/10.30574/wjarr.2020.6.3.0162

\begin{abstract}
The present study aimed to investigate the antidiabetic and anti-inflammatory effects of Trifolium alexandrinum (TA) and Trifolium Pretense (TP) against streptozotocin induced diabetic impairment in male rats. Forty adult Wistar albino male rats were divided into four groups: Group 1, Control; Group 2, streptozotocin (STZ); Group 3, STZ + TA -treated group and Group 4, STZ + TP-treated group. TA and TP showed a significant reduction in the blood glucose, glycosylated hemoglobin (Hb A1C) levels and elevation in insulin and C-peptide. They restored the glycogen content of liver and skeletal muscle, also showed improvements in the activities of $\alpha$-amylase, carbohydrate metabolic enzymes, lipase and lipid profile. Treatment with TA and TP extracts resulted in an improvement of the oxidative parameters and enhancement in the antioxidant enzymes in the pancreas and liver. While, pancreatic TNF- $\alpha$, IL-1 $\beta$, IL-6, NO, iNos and caspase- 3 levels were significantly reduced with the treatment of TA and TP extracts. Administration of TA and TP extracts to diabetic rats revealed elevation in the GLUT4 levels of the skeletal muscle and pancreas. They caused up regulation in pancreatic GLUT2 gene expression. TA and TP extracts showed signs of regeneration of $\beta$-cells and improvement in the pancreatic tissue. It could be concluded that TA and TP extracts possess antioxidant and hypoglycemic potential resulting in reduction of the elevated oxidative stress and pro-inflammatory cytokines.
\end{abstract}

Keywords: Trifolium alexandrinum; Trifolium pratense; Diabetes; Carbohydrate metabolic enzymes; Proinflammatory cytokines

\section{Introduction}

Diabetes mellitus (DM) is a chronic metabolic disease that is related to a variety of genetic and environmental factors [1]. DM is a heterogeneous metabolic disorder resulting from defective insulin secretion, resistance to insulin action or both leading to prolonged hyperglycemia with disarrangement carbohydrate, lipid and protein metabolism [2].

Diabetes mellitus type 2 (T2DM; non-insulin-dependent diabetes or adult-onset diabetes), is an endocrine disorder characterized by high blood sugar causing insulin resistance (IR) and relative insulin deficiency [3].

Hyperglycemia is responsible for the formation of free radicals, autooxidation of glucose and lipid peroxidation as well as disturbance of the antioxidant defense system [2]. According to the ADA, the chronic hyperglycemia is associated with long-term damage, dysfunction and failure of different organs, especially the eyes, kidneys, nerves, heart and blood vessels [4].

In spite of the availability of various antidiabetic agents and its secondary complications continue to become a major problem in the world population, medicinal plants and their bioactive compound are used as an alternative method to treat the diabetic patient throughout the world and popular as nutraceutical [5].

\footnotetext{
* Corresponding author: Abdou Heba Mohamed
} 
The health properties of Trifolium sp., Shows antiseptic, analgesic, antioxidant and anti-inflammatory properties [6]. The biological activity of Trifolium sp., due to the presence of interesting natural bioactive compounds, such as flavonoid glycosides, clovamides and polyphenols [7].

TA and TP possess great amounts of phytoestrogens [8]. These plants are used to treat and relieve symptoms in postmenopausal women [9]. Estrogen regulates several metabolic processes, including glucose and lipid metabolism, body weight, adipose tissue distribution, caloric intake and energy expenditure in both men and women [10].

The present study was carried out to investigate the efficiency of the two Fabaceae extracts; TA and TP in reducing the hyperglycemia, diabetic impairment and oxidative stress in the STZ induced diabetic rats and to assess their therapeutic potential for treatment of diabetes mellitus.

\section{Material and methods}

\subsection{Chemicals}

Streptozotocin (STZ) (2-Deoxy-2-(3-methyl-3-nitrosourea) -1-D-glucopyranose) is a synthetic nitrosoureido glucopyranose, pale yellow, sterilized powder. It was purchased from Sigma-Aldrich Chemical Co (www.sigmaldrich.com) St. Louis, MO, USA.

Trifolium pratense (TP) Linn. (Family: Fabaceae) (common name Red clover) was purchased from Nature's Way, Inc. Springville, Utah 84663 (USA) and then the powdered material in the capsules were soaked in methanol then filtered and lyophilized.

Kits were purchased from Biodiagnostic and research reagents Co. (Cairo, Egypt). All reagents and chemicals used were of analytical grade, other chemicals were of the highest purity commercially available.

\subsection{Preparation of methanolic extracts of Trifolium alexandrinum}

Aerial parts (leaves, stem and flowers) of the plant, Trifolium alexandrinum (TA) Linn. (Family: Fabaceae) (common name: Egyptian clover, Berseem clover) were collected during the vegetative and flowering growth stage from different localities of Alexandria, Egypt by Safaa Abd Elsalam Mohamed, lecturer of plant taxonomy and palynology, Biological and Geological Sciences Department, Faculty of Education, Alexandria University. The plant was collected from fields in the morning and immediately taken to the laboratory and it was taxonomically identified, according to its morphological characters [11]. The plant extract was done according to Khan et al [12]. The aerial parts of it were collected, washed with tap water, then with distilled water, dried under shade. The chopped plant was grinded into fine powder using an electric grinder to obtain a fine powder. The powdered material was soaked in $80 \%$ methanol for a period of 1 week at room temperature and then filtered using a Buchner funnel and Whatman No.1 filter paper. The filtrate was lyophilized for dryness using a Freeze-dry system/Lyph lock 4.5 (Labconco) at the Environmental Sciences Department, Faculty of Science, Alexandria University. After lyophilization, the resulting the dried extracts of TA plant. The TA crude extracts were kept in a sterile labeled container and refrigerated at $4{ }^{\circ} \mathrm{C}$ for further assessment.

\subsection{Induction of diabetes}

Thirty adult Wistar albino male rats were injected intraperitoneally (i.p) by a single dose of streptozotocin (STZ) at a dose level of $40 \mathrm{mg} / \mathrm{kg}$ b.w. that freshly dissolved in cold sodium citrate buffer (0.1 M/L; pH 4.5) [13]. Three days after the STZ injection, the blood was withdrawn from the tail vein and the glucose level was determined. Rats were diabetic when their fasting blood glucose levels were more than $200 \mathrm{mg} / \mathrm{dL}$.

\subsection{Experimental animals and groups}

In the present study, forty adult male albino rats weighing 180-200 g, 11-12 weeks old were used. Rats were obtained from the animal Care Unit, Department of Home Economics, Faculty of Agriculture, Alexandria University, Egypt. Rats were housed in stainless steel wire cages placed in a well-ventilated animal house kept on basal diet and tap water ad libitum and maintained under constant laboratory conditions of (temperature: $22 \pm 3{ }^{\circ} \mathrm{C}$, photoperiod: $12 / 12$-h light/dark cycle). The local committee approved the design of the experiments and protocols were carried out according to the guidelines of the National Institutes of Health (NIH).

After induction of diabetes, the diabetic rats were randomly allocated to 3 groups (10 rats each): 1. (Diabetic group); STZ-treated group; 2. (Diabetic+TA); Diabetic+Trifolium alexandrinum -treated group): diabetic rats treated orally by 
gavage with TA methanolic at a dose of $200 \mathrm{mg} / \mathrm{kg} \mathrm{B.W.} \mathrm{[12]} \mathrm{once} \mathrm{a} \mathrm{day} \mathrm{for} 15$ consecutive days; 3. (Diabetic+TP); Diabetic+ Trifolium pratense -treated group): diabetic rats treated orally by gavage with TP methanolic extract at a dose of $250 \mathrm{mg} / \mathrm{kg} \mathrm{B.W.} \mathrm{[14]} \mathrm{once} \mathrm{a} \mathrm{day} \mathrm{for} 15$ consecutive days. Ten rats received distilled water and were used as a control group.

\subsection{Blood and tissue sampling}

\subsubsection{Blood collection}

At the end of the experiment, rats were fasted overnight and blood samples were collected from anesthetized rats of all groups by cardiac puncture using a sterile syringe for determination of biochemical analysis. Part of the blood samples were put immediately into silicon disposable glass tubes with ethylene diamine tetra-acetic acid (EDTA) (El-Gomhorya Co., Egypt) as an anticoagulant and placed immediately on ice for the determination of glycosylated hemoglobin (Hb A1c) concentration. The other part of collected blood sample from all experimental groups was allowed to coagulate in a sterilized centrifuge tube in frozen ice for a few min. and centrifuged at 3000 r.p.m. for $10 \mathrm{~min}$. to separate blood serum. Then the obtained serum, kept at $-20^{\circ} \mathrm{C}$ until analyses of the required parameters.

\subsubsection{Preparation of pancreas, liver and skeletal muscle tissue homogenates}

The pancreas, liver and skeletal muscles were dissected and isolated from all experimental groups. These organs were cleaned from the blood and adhering matter and washed by chilled cold saline solution $(0.9 \% \mathrm{NaCl})$, parts of isolated tissues were immediately dried, immersed in RNA Later and kept at $-80{ }^{\circ} \mathrm{C}$ until molecular analysis. Then, $0.5 \mathrm{~g}$ of pancreas, liver and muscles were minced and homogenized separately in $2 \mathrm{ml}$ cold buffer ( $50 \mathrm{mM}$ potassium phosphate, $\mathrm{pH}$ 7.5, $1 \mathrm{mM}$ EDTA/g tissue) using tissue homogenizer (Potter-Elvehjem type Homogenizer) for $5 \mathrm{~min}$. The Homogenates were then centrifuged at $4000 \mathrm{rpm}$ for $15 \mathrm{~min}$. (Hettich zentrifugen, Universal $32 \mathrm{R}$, Germany) at $4{ }^{\circ} \mathrm{C}$. The supernatants were stored at $-80^{\circ} \mathrm{C}$ for determination of biochemical parameters. Other Parts of pancreas from each experimental group were sliced and immediately fixed in $10 \%$ formalin for histological examination.

\subsection{Biochemical parameters}

The serum glucose level was measured using a spectrophotometric assay kit.

C-peptide serum levels were determined by the Mercodia C-peptide ELISA, Mercodia AB, Uppsala, Sweden, according to the manufacturer's protocol. Liver and muscle glycogen levels were assessed by the Glycogen Assay kit. Whole blood was used in the analysis of $\mathrm{HbA1c}$ with the aid turbidimetric immunoassay kit.

Serum $\alpha$-amylase activity (EC: 3.2.1.1) Assay kit (Colorimetric) (ab102523) detects activity of $\alpha$-amylase through a twostep reaction.

Hepatic hexokinase (HK; EC: 2.7.1.1) Assay kit (Colorimetric) (ab136957), the assay is simple, sensitive and rapid and can detect HK activity even less than $0.1 \mathrm{mU} /$ well.

Hepatic glucokinase activity (GK; EC: 2.7.1.12) was determined using the method of Davidson and Arion [15].

Hepatic glucose-6-phosphate dehydrogenase (G6Pd; EC: 1.1.1.49) activity was performed at $37^{\circ} \mathrm{C}$ in the spectrophotometer in accordance with the Beutler [16] method. This method is based on the fact that NADPH, which is formed as a result of reducing NADP+, yields absorbance at $340 \mathrm{~nm}$.

Hepatic glucose-6-phosphatase (G6P; EC: 3.1.3.9) activity was measured using the method of Alegre et al [17].

Serum aspartate aminotransferase (AST; EC: 2.6.1.1) and alanine transaminase (ALT; EC: 2.6.1.2) activities were assayed spectrophotometrically according to Reitman and Frankel [18].

Serum alkaline phosphatase (ALP; EC: 3.1.3.1) activity was measured colorimetrically according to Belfield and Goldberg [19].

Serum lactate dehydrogenase (LDH; EC: 1.1.1.27) activity was measured according to the technique described by Vassault et al [20]. 
The serum total cholesterol (TC) level was determined using a commercial kit (Sigma, USA. The HDL-cholesterol concentration was measured according to the method descriptive by Lopes-Virella et al [21]. The serum triglyceride (TG) concentration was measured enzymatically using a kit from Sigma Chemical Co. LDL- cholesterol and VLDLcholesterol were determined according to Friedewald et al [22].

Serum lipase activity (EC: 3.1.1.3) was measured using the method of Tietz and Shuey [23].

The concentration of malondialdehyde (MDA), a product of lipid peroxidation was measured as an indicator of oxidative stress in pancreas and liver tissues according to the method described by Varshney and Kale [24]. Reduced glutathione (GSH) was measured spectrophotometrically at $412 \mathrm{~nm}$ according to the method described by Jollow et al [25]. Superoxide dismutase (SOD; EC: 1.15.1.1), catalase (CAT; EC: 1.11.1.6) and glutathione peroxidase (GPx; EC: 1.11.1.9) activities were determined in the pancreas and liver tissues by the method of Nishikim et al [26], Abei [27] and Rotruck et al [28], respectively. The nitric oxide (NO) level in the pancreas and liver tissues was determined by the method of Montgomery and Dymock [29]. Advanced glycated end products (AGEs) concentration was measured using Cell Biolabs' OxiSelect ${ }^{\mathrm{TM}}$ AGE Competitive ELISA Kit. Antioxidant capacity determination is assayed by the method of Koracevic et al [30].

Tumor Necrosis factor alpha (TNF- $\alpha$ ), Interleukin-1 $\beta$ (IL-1 $\beta$ ), Interleukin-6 (IL-6), INOS and pancreatic caspase-3 concentration were estimated using ELISA kits, according to the manufacturer's protocol. Glucose transporter 4 (GLUT4) concentrations in the muscle and pancreas tissues was measured using a sandwich enzyme immunoassay kit.

\subsection{Molecular study}

\subsubsection{Isolation of total RNA from pancreas tissue}

Total RNA was isolated from pancreas using RNA-spinTM Total RNA extraction Kit (iNtRON Biovision, Egypt Co.) according to the manufacturer's instructions.

\subsubsection{Quantitative reverse transcriptase ( $q R T) Q R T-P C R$}

Glucose transporter-2 (GLUT2) gene expression was analyzed by quantitative reverse transcription-PCR (RT-PCR; illumina) using a real-time SYBR Green gene expression assay kit (QIAGEN). cDNA was directly prepared from isolated RNA using cDNA Synthesis kit; and mRNA levels of GLUT2 as well as the reference gene, B-ACTIN, were analyzed using gene-specific SYBR Green-based QuantiTect $®$ Primer assays (QIAGEN, Germany). qPCR was performed in a reaction volume of $25 \mu \mathrm{L}$ according to the manufacturer's instructions. Briefly, $12.5 \mu \mathrm{L}$ of master mix, $2.5 \mu \mathrm{L}$ of assay primers $(10 \times)$ and $10 \mu \mathrm{L}$ of template cDNA (100 ng) were added to each well. After a brief centrifugation, PCR plate was subjected to 35 cycles under the conditions in Table (1).

Table 1 Real-time PCR thermal cycling conditions and the sequence of the primer

\begin{tabular}{|c|c|c|c|c|c|}
\hline \multicolumn{6}{|c|}{ Real-time PCR thermal cycling conditions } \\
\hline \multicolumn{2}{|l|}{ Stage } & Temperature & \multicolumn{2}{|c|}{ Time } & Number of cycles \\
\hline \multicolumn{2}{|c|}{ Initial denaturation } & 95 & \multicolumn{3}{|c|}{$10-15 \min$} \\
\hline \multicolumn{2}{|l|}{ Denaturation } & 95 & \multicolumn{2}{|c|}{$10 \mathrm{sec}$} & \multirow{3}{*}{$35-55$} \\
\hline \multicolumn{2}{|l|}{ Annealing } & 55 & \multicolumn{2}{|c|}{$15 \mathrm{sec}$} & \\
\hline \multicolumn{2}{|l|}{ Extension } & 72 & \multicolumn{2}{|c|}{$15-30 \mathrm{sec}$} & \\
\hline \multicolumn{6}{|c|}{ The sequence of the primer } \\
\hline \multirow{2}{*}{ Gene } & \multicolumn{5}{|c|}{ GLUT-2 } \\
\hline & \multicolumn{3}{|c|}{$\begin{array}{l}\text { designed from rat glucose transporter } \\
\text { type } 2\end{array}$} & \multicolumn{2}{|l|}{ B-ACTIN } \\
\hline $\begin{array}{l}\text { Forward } \\
\text { primer }\end{array}$ & \multicolumn{3}{|c|}{ TGGGTTCCTTCCAGTTCG } & \multicolumn{2}{|c|}{ AGGCCGGCTTCGCGGGCGA } \\
\hline Reverse primer & \multicolumn{2}{|c|}{ AGGCGTCTGGTGTCGTATG } & \multicolumn{3}{|c|}{ TGCTCCTCAGGGGCCACACG } \\
\hline \multicolumn{6}{|c|}{ According to Matsuoka et al [32] } \\
\hline
\end{tabular}


All samples and controls were run in triplicate. The quantitative RT-PCR data were analyzed using a comparative threshold (Ct) method and the fold inductions of samples were compared with the untreated samples. B-ACTIN was used as an internal reference gene to normalize the expression of specific genes. The gene expression level was then calculated as previously described by Yuan et al [31].

\subsection{Histological examination}

Pancreatic tissues were collected after animal sacrifice for the histopathological examination purposes. All tissue samples were fixed in $10 \%$ formalin solution, and then treated with conventional grade of alcohol and xylene. Then cut into $5 \mu \mathrm{m}$-thick sections using a microtome (Leica RM2255, Germany) and stained with hematoxylin and eosin (H and E) stains, for microscopic investigation. The slides were examined and photographed with an Olympus UTU1X-2 camera connected to an Olympus CX41 microscope (Tokyo, Japan).

\subsection{Statistical methods}

The present data subjected to statistical analysis. Statistical analysis was done using Statistical Package for Social Sciences (SPSS) computer program, version 20.00 produced by IBM Software, Inc. Chicago, USA. The data were analyzed by one-way analysis of variance (ANOVA) and the group means were compared with Tukey's post hoc test [33]. All data were presented as means \pm standard error (SE). Differences were considered significant at $\mathrm{P} \leq 0.05$.

\section{Results}

3.1. Effect of Trifolium alexandrinum (TA) and Trifolium pratense (TP) extracts on the levels of serum glucose, insulin, C-peptide, glycogen in liver and muscle and blood glycosylated hemoglobin (Hb A1c) of diabetic male rats

As shown in Table 2 levels of serum glucose and blood Hb A1c of untreated diabetic group were significantly (p $\leq 0.05$ ) increased as compared to control group. In contrast, there were significant $(p \leq 0.05)$ decrease in the levels of serum insulin, C-peptide and glycogen in the liver and muscle as compared to control group.

On the other hand, administration of TA and TP extracts to diabetic rats caused significant $(\mathrm{p} \leq 0.05)$ reduction in glucose and $\mathrm{Hb} \mathrm{A} 1 \mathrm{c}$ levels and significant $(\mathrm{p} \leq 0.05)$ increases in the levels of insulin, $\mathrm{C}$-peptide and glycogen in the liver and muscle when compared to the untreated diabetic group.

Table 2 Effect of Trifolium alexandrinum (TA) and Trifolium pratense (TP) extracts on the levels of serum glucose, insulin, C-peptide, glycogen in liver and muscle and blood glycosylated hemoglobin (Hb A1c) of diabetic male rats

\begin{tabular}{|c|c|c|c|c|}
\hline Parameters & Control & Diabetic & Diabetic+TA & Diabetic+TP \\
\hline Glucose (mg/dl) & $126.86 \pm 5.20$ & $311.42 \pm 15.95$ a & $138.29 \pm 9.76^{b}$ & $137.43 \pm 11.35$ \\
\hline Insulin $(\mu \mathrm{U} / \mathrm{L})$ & $10.86 \pm 0.79$ & $2.41 \pm 0.47$ a & $8.08 \pm 0.60^{b}$ & $8.10 \pm 0.55 \mathrm{~b}$ \\
\hline C-peptide (ng/ml) & $8.43 \pm 0.18$ & $5.01 \pm 0.29 \mathrm{a}$ & $7.60 \pm 0.29 b$ & $7.56 \pm 0.26 \mathrm{~b}$ \\
\hline Liver glycogen (mg/g tissue) & $5.69 \pm 0.21$ & $2.89 \pm 0.23$ & $5.19 \pm 0.27 \mathrm{~b}$ & $5.13 \pm 0.26^{b}$ \\
\hline Muscle glycogen (mg/g tissue) & $57.24 \pm 2.76$ & $27.10 \pm 1.54{ }^{\mathrm{a}}$ & $55.06 \pm 3.38 \mathrm{~b}$ & $52.24 \pm 2.60^{b}$ \\
\hline Hb A1c (\%) & $5.14 \pm 0.15$ & $13.59 \pm 0.51^{\mathrm{a}}$ & $6.06 \pm 0.40^{b}$ & $5.59 \pm 0.37$ b \\
\hline
\end{tabular}

\subsection{Effect of Trifolium alexandrinum (TA) and Trifolium pratense (TP) extracts on the activities of serum $\alpha$ - amylase and hepatic carbohydrate metabolizing enzymes of diabetic male rats}

Table 3 showed that serum $\alpha$-amylase activity of untreated diabetic group were significantly ( $\leq \leq 0.05)$ increased while the activities of hepatic hexokinase (HK), glukokinase (GK) and glucose-6-phosphate dehydrogenase (G6Pd) were significantly $(\mathrm{p} \leq 0.05)$ decreased as compared to control group. Also, untreated diabetic rats exhibited significant $(\mathrm{p} \leq 0.05)$ increase in hepatic glucose-6-phosphatase (G6P) activity when compared to control group. 
On contrast, TA and TP extracts treatment caused significant $(\mathrm{p} \leq 0.05)$ decrement in the activity of serum $\alpha$-amylase and significant $(\mathrm{p} \leq 0.05)$ increment in the activity of hepatic HK, GK and G6Pd as compared to untreated diabetic rats. In addition, a significant $(\mathrm{p} \leq 0.05)$ decrement in the activity of hepatic G6P in TA and TP -treated groups was observed as compared to untreated diabetic rats.

Table 3 Effect of Trifolium alexandrinum (TA) and Trifolium pratense (TP) extracts on the activities of serum $\alpha$-amylase and hepatic carbohydrate metabolizing enzymes of diabetic male rats

\begin{tabular}{lllll}
\hline Parameters & Control & Diabetic & Diabetic+TA & Diabetic+TP \\
\hline$\alpha$-amylase $(\mathrm{mU} / \mathrm{ml})$ & $101.29 \pm 5.39$ & $165.11 \pm 3.56^{\mathrm{a}}$ & $91.33 \pm 5.05^{\mathrm{b}}$ & $86.40 \pm 4.30^{\mathrm{b}}$ \\
$\mathrm{HK}(\mathrm{nM} / \mathrm{mg}$ tissue $)$ & $342.00 \pm 8.85$ & $276.71 \pm 10.80^{\mathrm{a}}$ & $314.10 \pm 3.63 \mathrm{~b}$ & $320.29 \pm 10.05^{\mathrm{b}}$ \\
GK $(\mu \mathrm{M} / \mathrm{mg}$ tissue $)$ & $6.49 \pm 0.43$ & $3.54 \pm 0.42^{\mathrm{a}}$ & $5.21 \pm 0.14 \mathrm{~b}$ & $5.90 \pm 0.29 \mathrm{~b}$ \\
G6Pd $(\mathrm{mU} / \mathrm{mg}$ tissue $)$ & $86.00 \pm 3.08$ & $43.50 \pm 2.14^{\mathrm{a}}$ & $76.93 \pm 3.44 \mathrm{~b}$ & $75.79 \pm 4.78 \mathrm{~b}$ \\
G6P $(\mathrm{U} / \mathrm{mg}$ tissue $)$ & $13.36 \pm 0.33$ & $22.54 \pm 0.50^{\mathrm{a}}$ & $12.74 \pm 0.23 \mathrm{~b}$ & $13.73 \pm 0.33^{\mathrm{b}}$ \\
\hline
\end{tabular}

Means in the same row with no superscript letter are not significantly different $(p \geq 0.05)$.

a: The mean values are significantly different in comparison with control group $(\mathrm{P} \leq 0.05)$.

b: The mean values are significantly different in comparison with diabetic group $(\mathrm{P} \leq 0.05)$.

\subsection{Effect of Trifolium alexandrinum (TA) and Trifolium pratense (TP) extracts on the activities of serum liver function enzymes of diabetic male rats}

The activities of serum aspartate aminotransferase (AST), alanine aminotransferase (ALT), alkaline phosphatase (ALP) and lactate dehydrogenase $(\mathrm{LDH})$ were significantly $(\mathrm{p} \leq 0.05)$ elevated in untreated diabetic rats when compared to control group (Table 4).

Furthermore, administration of TA and TP extracts caused significant $(\mathrm{p} \leq 0.05)$ decrease in the activities of these enzymes as compared to the untreated diabetic group.

Table 4 Effect of Trifolium alexandrinum (TA) and Trifolium pratense (TP) extracts on the activities of serum liver function enzymes of diabetic male rats

\begin{tabular}{|c|c|c|c|c|}
\hline Parameters & Control & Diabetic & Diabetic+TA & Diabetic+TP \\
\hline AST (U/L) & $176.14 \pm 14.30$ & $248.57 \pm 16.20^{a}$ & $195.71 \pm 6.76^{b}$ & $186.43 \pm 11.68^{b}$ \\
\hline $\operatorname{ALT}(\mathrm{U} / \mathrm{L})$ & $40.57 \pm 1.94$ & $55.71 \pm 4.00^{\mathrm{a}}$ & $40.00 \pm 4.14 \mathrm{~b}$ & $37.14 \pm 5.18^{b}$ \\
\hline ALP (U/L) & $241.29 \pm 18.34$ & $655.86 \pm 106.14 \mathrm{a}$ & $357.14 \pm 40.00 \mathrm{~b}$ & $248.86 \pm 9.95$ b \\
\hline LDH (U/L) & $415.51 \pm 28.03$ & $777.00 \pm 43.01^{\mathrm{a}}$ & $453.30 \pm 32.39 \mathrm{~b}$ & $445.31 \pm 31.27 b$ \\
\hline
\end{tabular}

\subsection{Effect of Trifolium alexandrinum (TA) and Trifolium pratense (TP) extracts on serum lipid profile and lipase activity of diabetic male rats}

The results of the present study showed that untreated diabetic group displayed a significant $(\mathrm{p} \leq 0.05)$ increase in the concentration of serum TC, TG, LDL-C and VLDL-C while, the serum HDL-C concentration was significantly ( $\mathrm{p} \leq 0.05$ ) decreased compared with control group. In addition, the activity of serum lipase of untreated diabetic group was significantly $(\mathrm{p} \leq 0.05)$ decreased compared with control group (Table 5).

However, administration of TA and TP extracts to diabetic groups showed significant $(\mathrm{p} \leq 0.05)$ decreases in the concentration of serum TC, TG, LDL-C and VLDL-C and significant ( $\mathrm{p} \leq 0.05)$ increase in the serum HDL-C concentration as compared with the untreated diabetic group. Moreover, the activity of serum lipase showed significant ( $\mathrm{p} \leq 0.05$ ) increase after treatment with TA and TP extracts compared with the untreated diabetic group. 
Table 5 Effect of Trifolium alexandrinum (TA) and Trifolium pratense (TP) extracts on serum lipid profile and lipase activity of diabetic male rats

\begin{tabular}{lllll}
\hline Parameters & Control & Diabetic & Diabetic+TA & Diabetic+TP \\
\hline TC $(\mathrm{mg} / \mathrm{dl})$ & $91.86 \pm 4.78$ & $116.71 \pm 4.20^{\mathrm{a}}$ & $99.14 \pm 3.62^{\mathrm{b}}$ & $92.00 \pm 3.00^{\mathrm{b}}$ \\
TG $(\mathrm{mg} / \mathrm{dl})$ & $99.29 \pm 3.41$ & $180.86 \pm 12.09 \mathrm{a}$ & $87.50 \pm 8.45^{\mathrm{b}}$ & $92.00 \pm 5.31 \mathrm{~b}$ \\
LDL-C $(\mathrm{mg} / \mathrm{dl})$ & $23.14 \pm 6.92$ & $49.21 \pm 5.00^{\mathrm{a}}$ & $32.06 \pm 4.86^{\mathrm{b}}$ & $24.81 \pm 3.90^{\mathrm{b}}$ \\
VLDL-C $(\mathrm{mg} / \mathrm{dl})$ & $19.86 \pm 0.68$ & $36.17 \pm 4.02^{\mathrm{a}}$ & $17.51 \pm 1.69^{\mathrm{b}}$ & $18.40 \pm 1.06^{\mathrm{b}}$ \\
HDL-C $(\mathrm{mg} / \mathrm{dl})$ & $48.86 \pm 3.66$ & $31.29 \pm 0.47^{\mathrm{a}}$ & $49.57 \pm 3.87^{\mathrm{b}}$ & $48.86 \pm 2.47^{\mathrm{b}}$ \\
Lipase $(\mathrm{U} / \mathrm{L})$ & $29.67 \pm 2.24$ & $65.01 \pm 5.30^{\mathrm{a}}$ & $26.86 \pm 1.84 \mathrm{~b}$ & $24.39 \pm 1.60^{\mathrm{b}}$ \\
\hline
\end{tabular}

Means in the same row with no superscript letter are not significantly different $(p \geq 0.05)$.

a: The mean values are significantly different in comparison with control group ( $\mathrm{P} \leq 0.05)$.

b: The mean values are significantly different in comparison with diabetic group $(P \leq 0.05)$.

\subsection{Effect of Trifolium alexandrinum (TA) and Trifolium pratense (TP) extracts on oxidative stress markers and glycated end products (AGEs) in the pancreas and liver of diabetic male rats}

The obtained results showed significant $(p \leq 0.05)$ increase in the pancreatic and hepatic levels of oxidative stress markers; malondialdehyde (MDA), nitric oxide (NO) and glycated end products (AGEs) concentration in the untreated diabetic group in comparison with the control group (Table 6). While, the concentration of reduced glutathione (GSH) in both pancreas and liver tissues in the untreated diabetic group was significantly $(p \leq 0.05)$ reduced when compared to control group.

On the other hand, oral administration of either TA and TP extracts resulted in significant $(p \leq 0.05)$ reduction in the elevation of MDA, NO and AGEs levels and significant $(p \leq 0.05)$ enhancement in GSH concentration in both pancreas and liver when compared to the untreated diabetic group.

Table 6 Effect of Trifolium alexandrinum (TA) and Trifolium pratense (TP) extracts on oxidative stress markers and glycated end products (AGEs) in the pancreas and liver of diabetic male rats

\begin{tabular}{lllll}
\hline Parameters & Control & Diabetic & Diabetic+TA & Diabetic+TP \\
\hline Pancreas & & & & \\
MDA (nM/g tissue) & $13.77 \pm 1.11$ & $34.86 \pm 2.97^{\mathrm{a}}$ & $20.17 \pm 1.27^{\mathrm{b}}$ & $18.19 \pm 1.42^{\mathrm{b}}$ \\
NO $(\mu \mathrm{M} / \mathrm{g}$ tissue) & $1.77 \pm 0.17$ & $4.44 \pm 0.44^{\mathrm{a}}$ & $1.86 \pm 0.13^{\mathrm{b}}$ & $2.13 \pm 0.26^{\mathrm{b}}$ \\
AGEs $(\mu \mathrm{g} / \mathrm{g}$ protein) & $13.04 \pm 0.37$ & $19.30 \pm 0.53^{\mathrm{a}}$ & $13.79 \pm 0.47^{\mathrm{b}}$ & $13.76 \pm 0.47^{\mathrm{b}}$ \\
GSH (mg/g tissue) & $2.76 \pm 0.21$ & $1.69 \pm 0.10^{\mathrm{a}}$ & $2.31 \pm 0.15^{\mathrm{b}}$ & $2.50 \pm 0.10^{\mathrm{b}}$ \\
Liver & & & & \\
MDA (nM/g tissue) & $15.91 \pm 1.02$ & $36.28 \pm 2.66^{\mathrm{a}}$ & $17.74 \pm 0.94^{\mathrm{b}}$ & $22.03 \pm 0.63^{\mathrm{b}}$ \\
NO $(\mu \mathrm{M} / \mathrm{g}$ tissue) & $1.94 \pm 0.11$ & $4.73 \pm 0.13^{\mathrm{a}}$ & $1.99 \pm 0.09^{\mathrm{b}}$ & $2.27 \pm 0.16^{\mathrm{b}}$ \\
AGEs ( $\mu \mathrm{g} / \mathrm{g}$ protein) & $13.14 \pm 0.27$ & $20.30 \pm 0.43^{\mathrm{a}}$ & $14.07 \pm 0.37^{\mathrm{b}}$ & $13.09 \pm 0.38^{\mathrm{b}}$ \\
GSH $(\mathrm{mg} / \mathrm{g}$ tissue) & $14.56 \pm 0.08$ & $7.73 \pm 0.08^{\mathrm{a}}$ & $13.06 \pm 0.14^{\mathrm{b}}$ & $13.71 \pm 0.11^{\mathrm{b}}$ \\
\hline
\end{tabular}

\section{Values represented as means \pm SE.}

Means in the same row with no superscript letter are not significantly different $(p \geq 0.05)$.

a: The mean values are significantly different in comparison with control group $(P \leq 0.05)$.

b: The mean values are significantly different in comparison with diabetic group $(P \leq 0.05)$. 


\subsection{Effect of Trifolium alexandrinum (TA) and Trifolium pratense (TP) extracts on the antioxidant activities and total antioxidant capacity (TAC) in the pancreas and liver of diabetic male rats}

Results of the present study revealed that, diabetes induction resulted in significant $(p \leq 0.05)$ depletion of antioxidant enzyme activities (superoxide dismutase; SOD, catalase; CAT and glutathione peroxidase; GPX) and TAC in both pancreas and liver as compared to the control values (Table 7).

On the other hand, treatment with TA and TP extracts showed enhancement in the antioxidative status as demonstrated by significant $(p \leq 0.05)$ increase in the activities of the pancreatic and hepatic SOD, CAT, GPX and TAC level when compared to the untreated diabetic group.

Table 7 Effect of Trifolium alexandrinum (TA) and Trifolium pratense (TP) extracts on the antioxidant enzyme activities and total antioxidant capacity (TAC) in the pancreas and liver of diabetic male rats

\begin{tabular}{|c|c|c|c|c|}
\hline Parameters & Control & Diabetic & Diabetic+TA & Diabetic+TP \\
\hline \multicolumn{5}{|l|}{ Pancreas } \\
\hline SOD (U/mg protein) & $2.90 \pm 0.21$ & $1.46 \pm 0.22 \mathrm{a}$ & $2.84 \pm 0.15^{b}$ & $2.90 \pm 0.11 \mathrm{~b}$ \\
\hline CAT( U/mg protein) & $4.20 \pm 0.12$ & $3.16 \pm 0.22^{a}$ & $3.90 \pm 0.23 \mathrm{~b}$ & $4.00 \pm 0.06^{b}$ \\
\hline GPX (U/mg protein) & $22.67 \pm 0.52$ & $8.54 \pm 0.49$ a & $18.60 \pm 1.05 \mathrm{~b}$ & $22.50 \pm 0.25 \mathrm{~b}$ \\
\hline TAC (mM/g tissue) & $14.27 \pm 0.56$ & $8.44 \pm 0.44$ a & $13.0 \pm 0.39 \mathrm{~b}$ & $14.14 \pm 0.61^{b}$ \\
\hline \multicolumn{5}{|l|}{ Liver } \\
\hline SOD (U/mg protein) & $3.27 \pm 0.16$ & $1.34 \pm 0.17 \mathrm{a}$ & $3.10 \pm 0.15^{b}$ & $3.24 \pm 0.09 \mathrm{~b}$ \\
\hline CAT (U/mg protein) & $4.29 \pm 0.11$ & $3.03 \pm 0.17 \mathrm{a}$ & $4.06 \pm 0.37 \mathrm{~b}$ & $4.16 \pm 0.07 \mathrm{~b}$ \\
\hline GPX (U/mg protein) & $22.52 \pm 0.47$ & $8.83 \pm 0.45^{\text {a }}$ & $19.17 \pm 0.59 \mathrm{~b}$ & $21.78 \pm 0.35 \mathrm{~b}$ \\
\hline TAC (mM/g tissue) & $14.56 \pm 0.32$ & $7.73 \pm 0.43 \mathrm{a}^{\mathrm{a}}$ & $13.06 \pm 0.34 \mathrm{~b}$ & $13.71 \pm 0.43 \mathrm{~b}$ \\
\hline
\end{tabular}

3.7. Effect of Trifolium alexandrinum (TA) and Trifolium pratense (TP) extracts on the concentrations of tumor

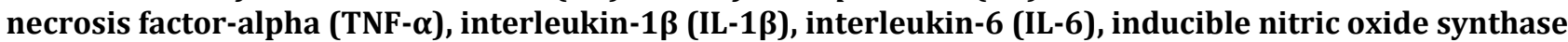
(iNOS) and caspase- 3 in the pancreas of diabetic male rats

The pancreatic concentrations of tumor necrosis factor alpha (TNF- $\alpha$ ), interleukin-1 $\beta$ (IL-1 $\beta$ ), interleukin-6 (IL-6), inducible nitric oxide synthase (iNOS) and caspase- 3 in untreated diabetic group were significantly $(P \leq 0.05)$ higher than those of the control group (Table 8).

Administration of TA and TP extracts significantly $(P \leq 0.05)$ decreased the pancreatic TNF- $\alpha$, IL-1 $\beta$, IL-6, iNOS and caspase- 3 concentrations in comparison to untreated diabetic group.

Table 8 Effect of Trifolium alexandrinum (TA) and Trifolium pratense (TP) extracts on the concentrations of tumor necrosis factor alpha (TNF- $\alpha$ ), interleukin-1 $\beta$ (IL-1 $\beta$ ), interleukin-6 (IL-6), inducible nitric oxide synthase (iNOS) and caspase- 3 in the pancreas of diabetic male rats

\begin{tabular}{|c|c|c|c|c|}
\hline Parameters & Control & Diabetic & Diabetic+TA & Diabetic+TP \\
\hline TNF- $\alpha$ (pg/g tissue) & $87.14 \pm 4.15$ & $135.86 \pm 5.39$ a & $111.57 \pm 4.16^{b}$ & $90.14 \pm 3.76$ b \\
\hline IL-1 $\beta$ (pg/g tissue) & $73.57 \pm 1.17$ & $109.71 \pm 1.92^{\mathrm{a}}$ & $93.29 \pm 1.44 \mathrm{~b}$ & $88.00 \pm 1.98 \mathrm{~b}$ \\
\hline IL-6 (pg/g tissue) & $163.57 \pm 2.46$ & $446.86 \pm 18.12^{a}$ & $252.43 \pm 22.21^{b}$ & $172.71 \pm 5.07 \mathrm{~b}$ \\
\hline iNOS (ng/g tissue) & $10.09 \pm 0.26$ & $18.16 \pm 0.48 \mathrm{a}$ & $12.57 \pm 0.77 \mathrm{~b}$ & $11.06 \pm 0.40^{b}$ \\
\hline Caspase -3 (ng/g tissue) & $212.71 \pm 1.44$ & $243.14 \pm 7.633^{a}$ & $221.14 \pm 6.37 \mathrm{~b}$ & $222.86 \pm 3.07 \mathrm{~b}$ \\
\hline
\end{tabular}




\subsection{Effect of Trifolium alexandrinum (TA) and Trifolium pratense (TP) extracts on the glucose transporter 4 (GLUT4) concentrations in the muscle and pancreas of diabetic male rats}

The concentration of glucose transporter 4 (GLUT4) in the muscle and pancreas of untreated diabetic rats was significantly $(p \leq 0.05)$ decreased as compared to control group (Table 9 ).

On contrast, administration of TA and TP extracts diabetic groups caused significant $(p \leq 0.05)$ increase in concentration of GLUT4 in the muscle and pancreas as compared to the untreated diabetic group.

Table 9 Effect of Trifolium alexandrinum (TA) and Trifolium pratense (TP) extracts on the glucose transporter 4 (GLUT4) concentrations in the muscle and pancreas of diabetic male rats

\begin{tabular}{lllll}
\hline Parameters & Control & Diabetic & Diabetic+TA & Diabetic+TP \\
\hline $\begin{array}{l}\text { Muscle } \\
\text { GLUT4 (ng/g tissue) }\end{array}$ & $205.43 \pm 2.11$ & $147.86 \pm 2.99^{\mathrm{a}}$ & $194.43 \pm 5.02^{\mathrm{b}}$ & $194.71 \pm 1.27^{\mathrm{b}}$ \\
$\begin{array}{l}\text { Pancreas } \\
\text { GLUT4 (ng/g tissue) }\end{array}$ & $105.43 \pm 2.11$ & $73.57 \pm 1.17^{\mathrm{a}}$ & $90.14 \pm 3.77^{\mathrm{b}}$ & $93.29 \pm 1.44^{\mathrm{b}}$ \\
\hline
\end{tabular}

Means in the same row with no superscript letter are not significantly different $(p \geq 0.05)$.

a: The mean values are significantly different in comparison with control group $(P \leq 0.05)$.

b: The mean values are significantly different in comparison with diabetic group $(P \leq 0.05)$.

\subsection{Effect of Trifolium alexandrinum (TA) and Trifolium pratense (TP) extracts on the glucose transporter 2 (GLUT2) gene expressions in the pancreas of diabetic male rats}

Pancreatic glucose transporter 2 (GLUT2) gene expressions of untreated diabetic rats was significantly ( $p \leq 0.05$ ) downregulated as compared to control group (Table 10).

On contrast, diabetic rats treated with TA and TP extracts exhibited significant ( $p \leq 0.05)$ upregulation in GLUT2 gene expression in the pancreas when compared to the untreated diabetic rats.

Table 10 Effect of Trifolium alexandrinum (TA) and Trifolium pratense (TP) extracts on the glucose transporter 2 (GLUT2) gene expressions in the pancreas of diabetic male rats (Fold change calculated in reference to control)

\begin{tabular}{lllll}
\hline Parameter & Control & Diabetic & Diabetic+TA & Diabetic+TP \\
\hline GLUT2 & $1.367 \pm 0.088$ & $0.447 \pm 0.038^{\text {a }}$ & $0.997 \pm 0.064^{\mathrm{b}}$ & $1.143 \pm 0.091^{\mathrm{b}}$ \\
\hline \multicolumn{4}{c}{$\begin{array}{c}\text { Values represented as means } \pm \text { SE. } \\
\text { Means in the same row with no superscript letter are not significantly different }(p \geq 0.05) . \\
\text { a: The mean values are significantly different in comparison with control group }(P \leq 0.05) . \\
\text { b: The mean values are significantly different in comparison with diabetic group }(P \leq 0.05) .\end{array}$}
\end{tabular}

\subsection{Histological examination in the pancreas tissue of male rats}

Control rats (Figures A1 and A2) revealed normal pancreatic architecture; large and regular well-defined islets of Langerhans which represented the endocrine portion of pancreatic lobules. They appeared as pale staining areas surrounded by thin capsule of connective tissue scattered in between the exocrine acini. The acini arranged in anastomosing branching cords with blood capillaries in between and consist of clusters of pyramidal shaped cells with pale -stained cytoplasm and central rounded nuclei.

While, the untreated diabetic rats (Figures B1and B2), showed disrupted architecture in the structure of the islets of Langerhans. They appeared distorted with degeneration of its cells and disturbance in cellular cord arrangement. Many islets cells revealed marked cytoplasmic vacuolation and pyknotic nuclei. Also, disturbance of the acinar pattern structure with area of pyknotic nuclei of some acinar cells and vacuolated acini. Presence of inflammatory cell infiltration, congestion, dilatation and thickening of the blood vessels. 
On the other hand, the histological changes of diabetic pancreas treated with TA and TP extracts were markedly reduced (Figures C1 and C2). These groups revealed moderate improvement in pancreatic cells and preserved the general architecture compared to the untreated diabetic group.
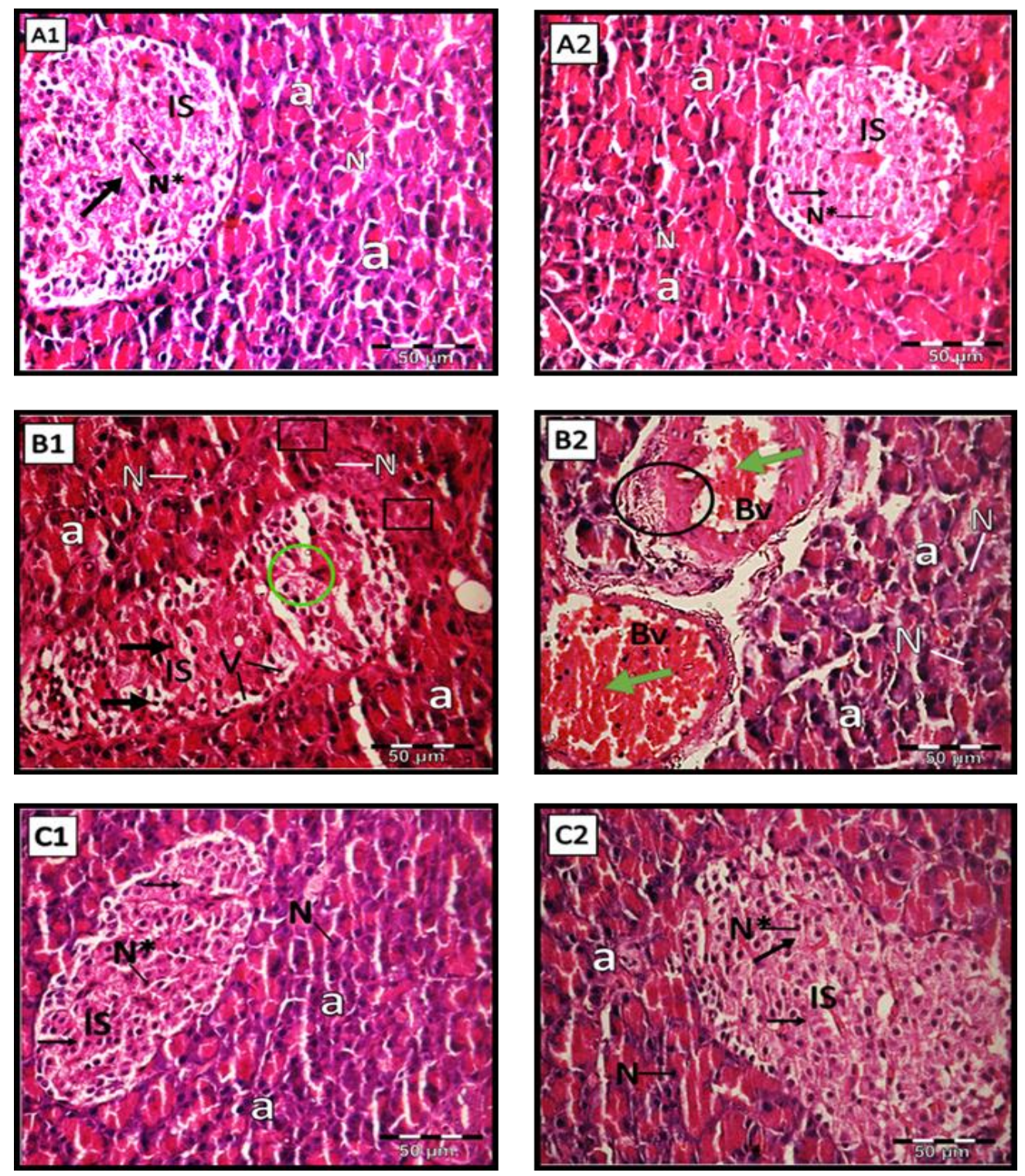

Figure 1 Photomicrographs of pancreatic sections of male rats; (A1 \& A2):control group showing normal pancreatic architecture; the closely packed pancreatic acini (a) pyramidal shaped cells with rounded nuclei (N), the pale-stained normal islets of Langerhans (IS) scattered in between acini with well-preserved cytoplasm (arrow) and nucleus (N*). untreated diabetic group (B1\& B2) showing disturbance of the acinar pattern structure (a), pyknotic nuclei of acinar cells $(\mathrm{N})$ with severe damage, dilation, thickening (black cicle) and congestion (green arrow) of the blood vessels (Bv). Islets of Langerhans (IS) with irregular outline, degeneration of its cells (green circle), vacuolated cytoplasm (V), many cells show pyknotic nuclei (black arrow). Presence of inflammatory cell infiltration (black square). TA \& TP -treated diabetic groups (C1 \& C2, respectively) showing moderate improvement in pancreatic architecture. H\&E, X400.

\section{Discussion}

Diabetes mellitus (DM) is one of the most commonly encountered metabolic diseases which endanger the life of millions of populations all over the world [3]. Therefore, there is an urgent need to continue working on the prevention and treatment of diabetes. New natural compounds are still continually being studied to develop novel therapies to better prevent or treat diabetes[34]. 
In the present study, streptozotocin (STZ) -induced diabetic rats showed elevation in glucose levels accompanied by reduction in insulin and C-peptide levels. The STZ mechanism includes partially selective destruction of pancreatic $\beta$ cells, which make cells less active and leading to poor sensitivity of insulin for glucose uptake by tissues that causes hyperglycemia [35]. This may be due to STZ result in accumulation of ROS and RNS inhibits the electron transport chain in mitochondria leading to reduced ATP production and uncoupling of glucose sensing from insulin secretion [36].

However, treatment of diabetic rats with Trifolium alexandrinum (TA) and Trifolium pratens (TP) extracts lead to reversed serum glucose, insulin and C-peptide levels nearly to the normal values. Taha et al [37] documented that the recovery of normal blood glucose levels in the treated diabetic rats could be directly attributable to the upregulated insulin and C-peptide levels. The improvement in insulin and C-peptide levels regarded to flavonoids-rich nutraceuticals, genistein and daidzein from TA and TP which exert antidiabetic effects [38]. They reported that the ability of daidzein to reduce the elevated glucose level in diabetic mice may be mediated by a main mechanism, including adenosine monophosphate-activated protein kinase (AMPK) activation and induction of glucose transporter 4 (GLUT4) translocation. Also, the elevation in insulin levels of diabetic rats treated with genistein may be attributed to its ability to regenerate $\beta$-cells and significant increase in the numerical density of islets that retained the ability to synthesize as well as secrete insulin [38].

In the current study, the untreated diabetic rats exhibited significant reduction in liver and muscle glycogen contents. This result is in agreement with those of Abdulrazaq et al [36] who explained that glycogen levels in insulin-dependent tissues (liver and skeletal muscle) decrease as they depend on insulin for the influx of glucose. It was also reported that, an impaired glycogen synthesis could promote the occurrence of hyperglycemia and diabetes [40].

Administration of TA and TP extracts restored the glycogen content of liver and skeletal muscle. As for TA and TP treatment are able to produce more insulin from pancreatic $\beta$-cells, insulin promote intracellular glycogen deposition in the liver of diabetic rats by stimulating glycogen synthase and inhibiting glycogen phosphorylase activities [41]. In addition, genistein and daidzein enhanced the rate of glycogenesis [38].

In the current study, the untreated diabetic rats exhibited elevation in HbA1C. These results are consistent with the findings of Joshi et al [42] who reported that the supra-physiological level of glucose non-enzymatically reacts with hemoglobin to form increased HbA1C.

On contrast, the high levels of HbAlc in diabetic rats significantly lowered by the treatment with TA and TP extracts; this could be due to the improvement in insulin secretion from the remnant pancreatic $\beta$-cells in diabetic rats which consequently resulting in improvement in glycemic control [38]. They added, these effects may be due to the presence of a high content of flavonoids, which acts synergistically as antioxidants. Moreover, presence of isoflavonoids in TP able to exert beneficial effects on glycosylation of hemoglobin through their antioxidative actions. This finding is supported by Govindaraj and Pillai [43] who reported that plant-derived isoflavones possess anti-glycation activity.

The elevation in $\alpha$-amylase activity observed in untreated diabetic rats could be due to the destruction of pancreatic tissue resulted from the oxidative stress generated in diabetic rats, which lead to the leakage of $\alpha$-amylase into blood circulation [42]. On the other hand, Treatment with TA and TP extracts antagonized the increment in serum $\alpha$-amylase activity in the diabetic rats. These results may due to the high potential of Trifolium extracts in lowering the postprandial hyperglycaemia through the inhibition of pancreatic $\alpha$-amylase enzyme activity [44]. This may be regarded to presence of quercetin and luteolin, as constituents of TA and TP, could inhibit pancreatic $\alpha$-amylase activity.

It is worthwhile to note that STZ -induced diabetic rats displayed reduction in the activities of insulin dependent enzymes; hexokinase (HK), glucokinase (GK) and glucose-6-phosphate dehydrogenase (G6Pd) in the liver. The reduction in liver HK activity in the of STZ-induced diabetic rats may be the reason for the diminished consumption of glucose in the system and increased blood glucose level due to lack of insulin and loss of insulin receptor $[35,45]$. Treatment with TA and TP extracts significantly increased the activity of hepatic HK, which indicates the effective utilization of glucose and direct stimulation of glycolysis in tissues with increased glucose removal from the blood circulation [46]. The administration of TA and TP extracts increased in the activity of hepatic GK suggesting that the antihyperglycaemic action observed was as a result of increased glucose utilization in the liver as well as skeletal muscle [36]. The treatment with TA and TP extracts showed significant increase in the activities of hepatic G6Pd that might be due to the elevation of insulin secretion. This might increase glucose utilization through the pentose phosphate pathway, interfering with the mitochondrial respiratory chain and promoting the peripheral glucose utilization by enhancing anaerobic glycolysis [47], as evidenced by the increased glycogen content in the liver. 
In the present study, the elevation in the activity of the liver glucose-6-phosphatase (G6P) in STZ -treated rats might be due to insulin deficiency, since insulin decreases gluconeogenesis by decreasing the activities of key enzymes such as G6P [47]. On the other hand, administration of TA and TP extracts had positively modulated activities of this enzyme, probably due to a significant increase in the levels of insulin. The reduction in the activity of this gluconeogenic enzyme reveal the reduced endogenous glucose production from liver [35]. The regulation of gluconeogenic flux by the extract might be one of the possible mechanisms for its antihyperglycemic nature. Moreover, restoration of hepatic glycogen by Trifolium extracts may be due to inhibition of G6P in the liver, thereby preventing conversion of glucose-6-phosphate to glucose [47].

The elevation in the activities of AST, ALT and ALP, suggesting the hepatotoxic effect of STZ, which is one of the characteristic changes in diabetes[13]. It is worthwhile to note that the TA and TP -treated diabetic rats displayed a significant reduction in the activities of these enzymes in the serum [48]. Therefore, the changes in the activities of these enzymes indicate control of gluconeogenesis as confirmed by the diminished serum glucose levels. Otherwise, genistein; one of the components of TA and TP, lowered the pathway enzymes in diabetic rats and inhibit the liver damage induced by STZ through its hypoglycemic potential [13]. In addition, biochanin A, found in TP, possesses multimechanistic hepatoprotective activity which could be attributed to its antioxidant, anti-inflammatory and immunemodulatory actions [49].

The elevated serum LDH activity in the untreated diabetic rats is associated with impaired glucose-stimulated insulin secretion [41]. Thus, increased activity of LDH interferes with normal glucose metabolism and insulin secretion in the cells of pancreas and it may therefore be directly responsible for insulin secretory defects in diabetes. However, treatment with TA and TP extracts to diabetic rats reverted the LDH activity to near normal most probably by regulating the proportion of pyruvate and NADH thereby indicating improved channeling of (pyruvate) glucose by mitochondrial oxidation [41].

In the present study, the diabetic rats exhibited hypercholesterolemia, elevated triglyceride (TG), elevated LDLC, elevated VLDL-C and reduced HDL-C level. These results indicate disturbances in lipid metabolism. The diabetics have abnormal lipid metabolism due to insulin deficiency in the body as a result of STZ -induced damage to pancreatic $\beta$-cells, since insulin can activate lipoprotein lipase (LPL), which hydrolyzes TGs [50]. Respecting to the present results, oral administration of TA and TP extracts to the diabetic rats improved the disturbance in the serum lipid profile. These data indicate the beneficial effects of TA and TP in improving lipid metabolism as supported by previous study, which demonstrates that TA and TP extracts could effectively prevent hypercholesterolemia as lipotropic factors [38]. In addition, oral administration of TA and TP extracts clearly reverted the activity of serum lipase nearly back to the non-diabetic rats. The two Trifolium species, rich source of flavonoids, characterized by their ability to inhibit lipase activity and thus reduce fat absorption [44]. The inhibitory action of lipase decreased the hydrolysis of dietary TGs into monoglycerides and free fatty acids, as it lowered the TC, LDL-C and TG and increased HDL-C levels in the serum [50].

The elevated levels of oxidative stress in untreated diabetic rats, which confirmed by the increase in malondialdehyde (MDA), nitric oxide (NO) and advanced glycation end products (AGEs) and decline in the activities of enzymatic antioxidants; superoxide dismutase (SOD), catalase (CAT), glutathione peroxidase (GPX), total antioxidant capacity (TAC) and reduced glutathione (GSH) in both pancreas and liver tissues may be due to the decreased activity of antioxidant enzymes along with the elevated lipids peroxidation in diabetic rats also, may be due to glycation of these enzymes [50]. The reduced activities of SOD and CAT in the liver observed during diabetes is sensitive indices of hepatocellular damage and are the most sensitive in liver injury, they may result in deleterious effects as a result of the accumulation of $\mathrm{O}^{2-}$ and $\mathrm{H}_{2} \mathrm{O}_{2}$ [48]. The generation of free radicals which are responsible for oxidative stress in diabetic animals and humans is known to be a sequence of one or a few of the mechanisms via glucose auto-oxidation, polyol pathway, protein glycation, lipids peroxidation and formation of AGEs along with inhibition of antioxidant enzyme activities [51]. In diabetic rats, GSH which co-substrate for GPx activity and cofactor for many enzymes, improves the scavenging capacity against free radicals induced oxidative stress [52]. Therefore, the depletion of GSH level in diabetic rats might be due to its utilization to alleviate the oxidative stress in diabetes [53]. The increased NO level may be related to the induction of nitric oxide synthase (NOS) isoenzymes this result is in accordance to those of Abdel Baky et al [54]. The overproduction of NO is considered as pro- inflammatory mediator leading to $\beta$-cells impairment or death thereby the rate of insulin synthesis is diminished [55].

Co administration of TA and TP extracts with STZ-diabetic group resulted in an improvement of the oxidative parameters and enhancement in the antioxidant enzymes; this might suggest a protective and prophylactic effect against STZ action and might be mediated through the neutralization of oxygen free radicals [12]. They reported that the depleted enzymatic and non-enzymatic anti-oxidants and the elevated lipids peroxidation of diabetic rats were restored significantly with the treatment of TA and TP extracts. Such effects may be mediated through the active 
phytoconstituents present in Trifolium extracts, like polyphenolic compounds and flavonoids, by either scavenging or quenching or neutralizing the free radicals or other ROS produced by STZ [7]. The indirect antioxidant protection of polyphenols has been shown by activation of 5' AMP-activated protein kinase (AMPK) pathway. This leads to the modulation of Nuclear factor (erythroid-derived 2)-like 2 (Nfr2), a transcription factor that controls many genes involved in antioxidant defense, activating endogenous defense systems [56]. Besides, Vlaisavljevic et al [8] reported that TP contain essential oil with best scavenging capacity to NO radical. Also, Dai et al [57] reported that quercetin has the potential to prevent excessive concentration of NO in pancreatic tissue.

In the current study, STZ -treated rats showed elevations in pancreatic tumor necrosis factor -alpha (TNF- $\alpha$ ) and interleukins (IL-1 $\beta$ and IL-6). These results are in agreement with other study which, reported that STZ treatment lead to the production of ROS as a result of STZ - $\beta$ cell interaction via GLUT-2 receptors, also this might be responsible for increasing production of proinflammatory cytokines (TNF- $\alpha$, IL-1 $\beta$, IFN- $\gamma$, IL-6, IL-18)[58]. Excessive IL-6 results in severe cytotoxicity in pancreatic islet cells and then leads to insulin resistance [59]. Moreover, oxidative stress affects adversely major signaling pathways and cellular mechanisms, including elevation of proinflammatory markers like TNF- $\alpha$ and ILs, which are directly associated with T2DM [42].

In the present study, elevated pancreatic TNF- $\alpha$, IL- $1 \beta$ and IL- 6 were significantly reduced with the treatment of TA and TP extracts. These results indicated the effects of TA and TP extracts in preventing the production of deleterious cytokines involved in the development and progression of diabetes [42]. Also, Fan et al [60] indicated that phytoestrogens seem to have anti-inflammatory effects by inhibiting TNF $-\alpha$, IL- $1 \beta$ and IL- 6 expression of mRNA production.

It was apparent from the present study that pancreatic caspase-3 and iNOS levels increased significantly in untreated diabetic rats. These results explained by Ibrahim and Abd El Maksoud [58] who revealed that elevation in tissue caspase- 3 activity in diabetic rats indicating increased tissue apoptosis due to increased ROS levels.

Furthermore, elevated levels of cytokines that are released by inflammatory cells in STZ exposed rats induce iNOS production and produce NO in pancreatic tissue [61] leading to cell damage and the surplus generation of NO in cells may restrain mitochondrial metabolism and contribute to elevated lipid peroxidation [62].

On the other hand, diabetic rats treated with TA and TP extracts exhibited decrement in iNOS levels. These results referred to that phytoestrogen exert anti-inflammatory effects by inhibiting NO and iNOS expression of mRNA production [60].

Daidzein and genistein reverted the increase in iNOS content which responsible for the production of the toxic free radical peroxinitrite [62]. Moreover, it was noticed that the cytoprotective effect of quercetin is associated with reduced expression of iNOS, decreased NO level and inhibition of NF- $\mathrm{BB}$ translocation [57].

On the other hand, administration of TA and TP extracts to diabetic rats a caused reduction in pancreatic caspase-3 level; this might be due to decline in pancreatic ROS [12]. Wang et al [45] reported that the diabetic apoptosis was inhibited after treatment with TP. They added that the anti-apoptotic effect of TP may be mediated by caspase-3. Also, SOD overexpression abrogated caspase-3 cleavage, DNA damage in type 2 diabetic mice [63].

The present observation elucidated that the levels of glucose transporter 4 (GLUT4) in both muscle tissues and pancreas were decreased in STZ -treated rats. These findings are in agreement with those of Cam et al[46] reported that the GLUT4 expression level decreased in skeletal muscle of STZ/nicotinamide -induced diabetic rats. Moreover, a common feature of adipose tissue and skeletal muscle metabolism is the increase in glucose influx in response to insulin mainly mediated by translocation of GLUT4 from storage vesicles into the plasma membrane [46].

Otherwise, the reduction of GLUT4 expression in skeletal muscles is an early step to develop insulin resistance and T2DM [2]. With the foregoing, defective insulin - insulin receptor activity and decreased GLUT4 arising from impaired cell membrane translocation of GLUT4 may play a significant role in the pathogenesis of T2DM [65].

The present study showed that treatment with TA and TP extracts to diabetic rats revealed elevation in the GLUT4 levels of the skeletal muscle and pancreas. This result agreed with Wang et al [45] who indicated increased muscle glycogen content, which is consistent with increased muscle glucose uptake regulated by GLUT4. 
Furthermore, isoflavones such as genistein, daidzein, quercetin and procyanidins have antidiabetic properties by upregulation of GLUT4 levels and its translocation in skeletal muscle cells and adipocytes [46]. Thus, the modulation of GLUT4 could be one of the mechanisms involved with the anti-diabetic activity of the TA and TP extracts.

The untreated diabetic rats exhibited down regulated gene expression level of pancreatic GLUT2. This result is consistent with the result of Yi et al [66] reported that the GLUT2 expression is down-regulated in pancreas of the diabetic rat model. This may be regarded to STZ enters the pancreatic $\beta$-cell via the low affinity GLUT2 in the plasma membrane and then accumulates within the cells causing DNA methylation and elicits diabetogenic action [2]. In addition, Rashid and Sil [61] postulated that elevated iNOS level in STZ administered animals resulted in an increment of NO that further reduces GLUT2 expression. Moreover, Prasath et al [55] observed that administration of STZ caused apoptosis of the pancreatic islets and consequently higher IL-1 $\beta$ level can also lead to cell membrane damage DNA strand breaks and thus down-regulation of GLUT2 mRNA expression.

The supplementation of TA and TP extracts to diabetic rats caused improvement in pancreatic GLUT2 gene expression. It was reported that enhanced expression of pancreatic insulin from the existing $\beta$-cells of islets are responsible for the upregulation of GLUT2. Taha et al [37] reported that Trifolium sp. enriched with alkaloids, flavonoid and polyphenolic compounds caused the elevation in glucose transporter proteins by enhancing the insulin signaling cascade. Mechanistically it has been demonstrated that flavonoids can act antidiabetic potential through glucose transporters by enhancing GLUT2 expression in pancreatic $\beta$-cells that triggered by PI3K/PKB and AMPK-mediated pathways [37]. Quercetin showed protective effects by decreasing oxidative stress, preservation of pancreatic $\beta$-cell integrity, enhanced insulin secretion and glucose uptake through GLUT2 membrane receptor [67].

In the present study, treatment with STZ lead to degeneration of the acinar cells with the presence of small vacuoles, also congestion, dilation and thickening of the blood vessels, degeneration of pancreatic islets with an irregular outline and vacuolated cytoplasm, these might be due to glucose toxicity and lipotoxicity [13].

Otherwise, the observed pancreatic $\beta$-cell toxicity induced by STZ explained the reduction in the insulin level, These regarded to the production of ROS that led to lipid peroxidation and DNA damage [37].

However, treatment of diabetic rats with TA and TP extracts showed signs of regeneration of $\beta$-cells and improvement in the pancreatic tissue. This could be attributed to some of the flavonoids present in Trifolium sp., their protective mechanism of $\beta$-cell survival is the suppression of oxidative stress and subsequent inhibition of the caspase cascade and DNA damage, therefore, protects them against autophagy, apoptosis, or necrosis [68].

\section{Conclusion}

It could be concluded that supplementation of TA or TP extracts caused diminution of the elevated oxidative stress, proinflammatory cytokines and histopathological alterations in STZ-treated rats. Furthermore, TA or TP extracts supplementation caused improvement in GLUT4 levels of the skeletal muscle and pancreas, as well as caused up regulation in pancreatic GLUT2 gene expression. It would be worthwhile to investigate the effect of TA or TP extracts as a supplement under medically supervised as natural anti-hyperglycemic agents with diabetic patients.

\section{Compliance with ethical standards}

\section{Acknowledgments}

The authors are thankful to the molecular lab at the, Medical Research Institute, Alexandria University, Egypt.

\section{Funding}

This research is funded by (STDF) Science \& Technology Development Fund, Ministry of Scientific Research, Egypt. Project number (22895).

\section{Consent for publication}

All co-authors agree to publish this manuscript in the World Journal of Advanced Research and Reviews (WJARR) 


\section{Disclosure of conflict of interest}

The authors declare that there are no conflicts of interest.

\section{Ethical approval}

The local committee approved the design of the experiments, and the protocol conforms to the guidelines of the National Institutes of Health (NIH).

\section{References}

[1] Jiao Y, Wang X, Jiang X, Kong F, Wang S and Yan C. (2017). Antidiabetic effects of Morus alba fruit polysaccharides on high-fat diet-and streptozotocin-induced type 2 diabetes in rats. Journal of ethnopharmacology, 199, 119-127.

[2] Wu J, Shi S, Wang H and Wang S. (2016). Mechanisms underlying the effect of polysaccharides in the treatment of type 2 diabetes, A review. Carbohydrate polymers, 144, 474-494.

[3] Kerner W and Brückel J. (2014). Definition, classification and diagnosis of diabetes mellitus. Experimental and clinical endocrinology and diabetes, 122, 384-386.

[4] American Diabetes Association (ADA). (2012). Diagnosis and classification of diabetes mellitus. Diabetes care 201, 33, S62-S69.

[5] Rumanti RM. (2017). Characterization of simplicia and chromatographic analysis of active extract lotus (Nelumbo nucifera Gaertn) which can reduce blood glucose in mice. Thesis, Faculty of Pharmacy, University of Sumatera Utara, 1-104.

[6] Umeno A, Horie M, Murotomi K, Nakajima Y and Yoshida Y. (2016). Antioxidative and antidiabetic effects of natural polyphenols and isoflavones. Molecules, 21(6), 708.

[7] Amer M, El-Habibi ES and El-Gendy A. (2004). Effects of Trifolium alexandrinum extracts on streptozotocininduced diabetes in male rats. Annals of nutrition and metabolism, 48(5), 343-347.

[8] Vlaisavljevic S, Kaurinovic B, Popovic M, Djurendic-Brenesel M, Vasiljevic B, Cvetkovic D and Vasiljevic S. (2014). Trifolium pratense $\mathrm{L}$. as a potential natural antioxidant. Molecules, 19, 713-725.

[9] Sobenin I, Myasoedova V and Orekhov A. (2016). Phytoestrogen-rich dietary supplements in anti-atherosclerotic therapy in postmenopausal women. Current pharmaceutical design, 22(2), 152-163.

[10] Ammar NM, El-Hawary SS, Mohamed DA, El-Halawany AM, El-Anssary AA, El-Kassem LA and El-Dosoky AH. (2016). Estrogenic activity including bone enhancement and effect on lipid profile of Luteolin-7-0-glucoside isolated from Trifolium alexandrinum L. in ovariectomized rats. Phytotherapy Research, 30(5), 768-773.

[11] Boulos L. (1999). Flora of Egypt, Azollaceae-Oxalidaceae. Al Hadara Publishing, Cairo, Egypt, 1, 249-281.

[12] Khan RA, Alkreathy HM, Saboorshah A, Ahmed M and Khan S. (2016). Protective effects of Trifolium alexandrinum L. against lung injury induced by environmental toxin CCl4 in experimental rats. Food \& nutrition research, 60(1), 30433.

[13] Ekperikpe US, Owolabi OJ and Olapeju BI. (2019). Effects of Parkia biglobosa aqueous seed extract on some biochemical, haematological and histopathological parameters in streptozotocin induced diabetic rats. J Ethnopharmacol, 228, 1-10.

[14] Abdou HM, Yousef MI, El Mekkawy DA and Al-Shami AS. (2016). Prophylactic neuroprotective efficiency of coadministration of Ginkgo biloba and Trifolium pretense against sodium arsenite-induced neurotoxicity and dementia in different regions of brain and spinal cord of rats. Food and Chemical Toxicology, 94, 112-127.

[15] Davidson AL and Arion WJ. (1987). Factors underlying significant underestimations of glucokinase activity in crude liver extracts, physiological implications of higher cellular activity. Archives of Biochemistry and Biophysics, 253(1), 156-167.

[16] Beutler E, Duron 0 and Kelly BM. (1963). Improvement method for determination of blood glutathione. The journal of laboratory and clinical medicine, 61, 882-888.

[17] Alegre M, Ciudad CJ, Fillat C and Guinovart JJ. (1988). Determination of glucose-6-phosphatase activity using the glucose dehydrogenase-coupled reaction. Analytical biochemistry, 173(1), 185-189. 
[18] Reitman S and Frankel S. (1957). A colorimetric method for the determination of serum glutamic oxalacetic and glutamic pyruvic transaminases. American journal of clinical pathology, 28, 56-63.

[19] Belfield A and Goldberg DM. (1970). Revised assay for serum phenyl phosphatase activity using 4-aminoantipyrine. Enzymes, 12, 561-573.

[20] Vassault A, Grafmeyer D, Naudin C, Dumont G, Bailly M, Henny J and Georges P. (1986). Protocole de validation de techniques. Annalitical journal of biological and clinical research, 44, 686-745.

[21] Lopes-Virella MF, Stone P, Ellis S and Colwell JA. (1977). Cholesterol determination in HDL-C separated by three different methods. Clinical chemistry, 23(5), 882-884.

[22] Friedewald WT, Levy RI and Fredrickson DS. (1972). Estimation of the concentration of low-density lipoprotein cholesterol in plasma, without use of the preparative ultracentrifuge. Clinical chemistry, 18(6), 499-502.

[23] Tietz NW and Shuey DF. (1993). Lipase in serum--the elusive enzyme, an overview. Clinical chemistry, 39(5), 746-756.

[24] Varshney R and Kale RK. (1990). Effects of calmodulin antagonists on radiation-induced lipid peroxidation in microsomes. International journal of radiation biology, 58(5), 733-743.

[25] Jollow DJ, Mitchell JR, Zampaglione NA and Gillette JR. (1974). Bromobenzene-induced liver necrosis. Protective role of glutathione and evidence for 3, 4-bromobenzene oxide as the hepatotoxic metabolite. Pharmacology, 11(3), 151-169.

[26] Nishikimi M, Rao NA and Yagi K. (1972). The occurrence of superoxide anion in the reaction of reduced phenazine methosulfate and molecular oxygen. Biochemical and biophysical research communications, 46(2), 849-854.

[27] Abei H. (1974). Catalase in vitro. Methods enzymatic analysis, 2, 673-684.

[28] Rotruck JT and Pope AL, Ganther HE, Swanson AB, Hafeman DG, Hoekstra W. (1973). Selenium, biochemical role as a component of glutathione peroxidase. Science, 179(4073), 588-590.

[29] Montgomery H and Dymock JF. (1961). Determination of nitrite in water. Analyst, 86, 414.

[30] Koracevic D, Koracevic G, Djordjevic V, andrejevic S and Cosic V. (2001). Method for the measurement of antioxidant activity in human fluids. Journal of clinical pathology, 54(5), 356-361.

[31] Yuan E, Liu B, Wei Q, Yang J, Chen L and Li Q. (2014). Structure activity relationships of flavonoids as potent $\alpha$ amylase inhibitors. Natural product communications, 9, 1173-1176.

[32] Matsuoka TA, Kaneto H, Stein R, Miyatsuka T, Kawamori D, Henderson E and Yamasaki Y. (2007). MafA regulates expression of genes important to islet $\beta$-cell function. Molecular Endocrinology, 21(11), 2764-2774.

[33] Gounden T, Moodley R and Jonnalagadda SB. (2018). Elemental analysis and nutritional value of edible Trifolium (clover) species. Journal of Environmental Science and Health B, 53(8), 487-492.

[34] Xiong H, Zhang S, Zhao Z, Zhao P, Chen L and Mei Z. (2018). Antidiabetic activities of entagenic acid in type 2 diabetic db/db mice and L6 myotubes via AMPK/GLUT4 pathway. Journal of ethnopharmacology, 211, 366-374.

[35] Kurup SB and Mini S. (2017). Protective potential of Averrhoa bilimbi fruits in ameliorating the hepatic key enzymes in streptozotocin-induced diabetic rats. Biomedicine \& pharmacotherapy, 85, 725-732.

[36] Abdulrazaq NB, Cho MM, Win NN, Zaman R and Rahman MT. (2012). Beneficial effects of ginger (Zingiber officinale) on carbohydrate metabolism in streptozotocin-induced diabetic rats. British Journal of Nutrition, 108(7), 1194-1201.

[37] Taha H, Arya A, Khan AK, Shahid N, Noordin MIB and Mohan S. (2018). Effect of Pseuduvaria macrophylla in attenuating hyperglycemia mediated oxidative stress and inflammatory response in STZ-nicotinamide induced diabetic rats by upregulating insulin secretion and glucose transporter-1, 2 and 4 proteins expression. Journal of Applied Biomedicine, 16(4), 263-273.

[38] Aly TA, Fayed SA, Ahmed AM and El Rahim EA. (2015). Effect of Egyptian radish and clover sprouts on blood sugar and lipid metabolisms in diabetic rats. Global Journal of Biotechnology \& Biochemistry, 10(1), 16-21.

[39] Cheong SH, Furuhashi K, Ito K, Nagaoka M, Yonezawa T, Miura Y and Yagasaki K. (2014). Daidzein promotes glucose uptake through glucose transporter 4 translocation to plasma membrane in L6 myocytes and improves glucose homeostasis in type 2 diabetic model mice. The Journal of nutritional biochemistry, 25, 136-143. 
[40] Kuai M, Li Y, Sun X, Ma Z, Lin C, Jing Y and Bian H. (2016). A novel formula Sang-Tong-Jian improves glycometabolism and ameliorates insulin resistance by activating PI3K/AKT pathway in type 2 diabetic KKAy mice. Biomedicine \& Pharmacotherapy, 84, 1585-1594.

[41] Sundaram R, Shanthi P and Sachdanandam P. (2014). Effect of tangeretin, a polymethoxylated flavone on glucose metabolism in streptozotocin-induced diabetic rats. Phytomedicine, 21, 793-799.

[42] Joshi DV, Patil RR and Naik SR. (2015). Hydroalcohol extract of Trigonella foenum-graecum seed attenuates markers of inflammation and oxidative stress while improving exocrine function in diabetic rats. Pharmaceutical biology, 53(2), 201-211.

[43] Govindaraj J and Pillai SS. (2015). Rosmarinic acid modulates the antioxidant status and protects pancreatic tissues from glucolipotoxicity mediated oxidative stress in high-fat diet, streptozotocin-induced diabetic rats. Molecular and cellular biochemistry, 404, 143-159.

[44] Tundis R, Marrelli M, Conforti F, Tenuta M, Bonesi M, Menichini F and Loizzo M. (2015). Trifolium pratense and T. repens (Leguminosae), edible flower extracts as functional ingredients. Foods, 4(3), 338-348.

[45] Wang K, Wang H, Liu Y, Shui W, Wang J, Cao P and Zhang Y. (2018). Dendrobium officinale polysaccharide attenuates type 2 diabetes mellitus via the regulation of PI3K/Akt-mediated glycogen synthesis and glucose metabolism. Journal of Functional Foods, 40, 261-271.

[46] Cam ME, Hazar-Yavuz AN, Yildiz S, Ertas B, Adakul BA, Taskin T and Kabasakal L. (2019). The methanolic extract of Thymus praecox subsp. skorpilii var. skorpilii restores glucose homeostasis, ameliorates insulin resistance and improves pancreatic $\beta$-cell function on streptozotocin/nicotinamide-induced type 2 diabetic rats. Journal of ethnopharmacology, 231, 29-38.

[47] Muruganathan U and Srinivasan S. (2016). Beneficial effect of carvone, a dietary monoterpene ameliorates hyperglycemia by regulating the key enzymes activities of carbohydrate metabolism in streptozotocin-induced diabetic rats. Biomedicine \& Pharmacotherapy, 84, 1558-1567.

[48] Sakeran MI, Zidan N, Rehman H, Aziz AT and Saggu S. (2014). Abrogation by Trifolium alexandrinum root extract on hepatotoxicity induced by acetaminophen in rats. Redox Report, 19(1), 26-33.

[49] Jalaludeen AM, Ha WT, Lee R, Kim JH, Do JT, Park C and Song H. (2016). Biochanin A ameliorates arsenic-induced hepato-and hematotoxicity in rats. Molecules, 21(1), 69.

[50] Al-Attar AM and Alsalmi FA. (2017). Effect of Olea europaea leaves extract on streptozotocin induced diabetes in male albino rats. Saudi journal of biological sciences, 26(1), 118-128.

[51] Goyal SN, Reddy NM, Patil KR, Nakhate KT, Ojha S, Patil CR and Agrawal YO. (2016). Challenges and issues with streptozotocin-induced diabetes-A clinically relevant animal model to understand the diabetes pathogenesis and evaluate therapeutics. Chemico-biological interactions, 244, 49-63.

[52] Ghosh GS, Bhattacharyya S, Rashid K and Sil PC. (2015). Curcumin protects rat liver from streptozotocin-induced diabetic pathophysiology by counteracting reactive oxygen species and inhibiting the activation of p53 and MAPKs mediated stress response pathways. Toxicology reports, 2, 365-376.

[53] Sheweita SA, Mashaly S, Newairy AA, Abdou HM and Eweda SM. (2016). Changes in oxidative stress and antioxidant enzyme activities in streptozotocin-induced diabetes mellitus in rats, Role of Alhagi maurorum extracts. Oxidative medicine and cellular longevity.

[54] Baky NA, Mohamed AM and Faddah LM. (2009). Protective effect of N-acetyl cysteine and/or pro vitamin A against monosodium glutamate-induced cardiopathy in rats. Journal of Pharmacology and Toxicology, 4(5), 178193.

[55] Prasath GS, Sundaram CS and Subramanian SP. (2013). Fisetin averts oxidative stress in pancreatic tissues of streptozotocin-induced diabetic rats. Endocrine, 44, 359-368.

[56] Gasparrini M, Giampieri F, Alvarez Suarez J, Mazzoni L, Forbes Hernandez T, Quiles J and Battino M. (2016). AMPK as a new attractive therapeutic target for disease prevention, the role of dietary compounds AMPK and disease prevention. Current drug targets, 17(8), 865-889.

[57] Dai X, Ding Y, Zhang Z, Cai X and Li Y. (2013). Quercetin and quercitrin protect against cytokine induced injuries in RINm5F $\beta$-cells via the mitochondrial pathway and NF- $\kappa B$ signaling. International journal of molecular medicine, 31(1), 265-271. 
[58] Ibrahim DS and Abd El-Maksoud MA. (2015). Effect of strawberry (Fragaria× ananassa) leaf extract on diabetic nephropathy in rats. International Journal of Experimental Pathology, 96(2), 87-93.

[59] Esposito K, Nappo F, Marfella R, Giugliano G, Giugliano F, Ciotola, M and Giugliano D. (2002). Inflammatory cytokine concentrations are acutely increased by hyperglycemia in humans, role of oxidative stress. Circulation, 106(16), 2067-2072.

[60] Fan H and Ryan RS. (2010). RT-PCR Protocols, 2nd Edition, Methods in Molecular Biology. Armidale NSW 2351 Australia, Springer Science and business media LLC, 630, 199-213.

[61] Rashid K and Sil PC. (2015). Curcumin enhances recovery of pancreatic islets from cellular stress induced inflammation and apoptosis in diabetic rats. Toxicology and applied pharmacology, 282, 297-310.

[62] Bae SH, Ha MH, Choi EY, Choi JI, Choi IS and Kim SJ. (2016). Effects of daidzein on alveolar bone loss and internal microstructures of bone in a rat model of experimental periodontitis, a study using micro-computed tomography. Journal of periodontal research, 51, 250-256.

[63] Kitada M, Kume S, Imaizumi N and Koya D. (2011). Resveratrol improves oxidative stress and protects against diabetic nephropathy through normalization of Mn-SOD dysfunction in AMPK/ SIRT1 independent pathway. Diabetes, 60, 634-643.

[64] Chen Z, Li W, Guo Q, Xu L, Santhanam RK, Gao X and Chen H. (2019). Anthocyanins from dietary black soybean potentiate glucose uptake in L6 rat skeletal muscle cells via up-regulating phosphorylated Akt and GLUT4. Journal of functional foods, 52, 663-669.

[65] Yan ST, Li CL, Tian H, Li J, Pei Y, Liu Y and Sun, BR. (2014). MiR-199a is overexpressed in plasma of type 2 diabetes patients which contributes to type 2 diabetes by targeting GLUT4. Molecular and cellular biochemistry, 397(12), 45-51.

[66] Yi L, Wei C and Fan W. (2017). Fine particulate matter (PM2. 5), a risk factor of rat gestational diabetes with altered blood glucose and pancreatic GLUT2 expression. Gynecological Endocrinology, 33, 611-616.

[67] Kittl M, Beyreis M, Tumurkhuu M, Fürst J, Helm K, Pitschmann A and Jakab M. (2016). Quercetin stimulates insulin secretion and reduces the viability of rat INS-1 beta-cells. Cellular Physiology and Biochemistry, 39(1), 278-293.

[68] Ghorbani A, Rashidi R and Shafiee-Nick R. (2019). Flavonoids for preserving pancreatic beta cell survival and function, A mechanistic review. Biomedicine \& Pharmacotherapy, 111, 947-957.

\section{How to cite this article}

Abdou HM, Mohammed NA, Hussein HK, Ghazaly KS and Abd El-latif HS. (2020). Antidiabetic and anti-inflammatory effects of two Fabaceae extracts against streptozotocin induced diabetic impairment in male rats. World Journal of Advanced Research and Reviews, 6(3), 12-29. 